\title{
Investigating University Student Violence and the Role Islamic Education can Play to Lessen This Phenomenon
}

\author{
Sadeq Hassan Al-Shudaifat ${ }^{1}$ \\ ${ }^{1}$ Faculty of Educational Sciences, The Hashemite University, Jordan \\ Correspondence: Sadeq Hassan Al-Shudaifat, Associate prof, Faculty of Educational Sciences, The Hashemite \\ University, P.O BOX 330127, Zarqa 13133, Jordan.
}

Received: December 8, 2019

Accepted: December 26, 2019

Online Published: December 27, 2019

doi:10.5430/ijhe.v9n2p40

URL: https://doi.org/10.5430/ijhe.v9n2p40

\begin{abstract}
This study aimed at investigating the causes of the university violence and the contribution of Islamic education in confronting it. The sample of the study consisted of (386) students studying at the Hashemite University during the second semester of the academic year 2012/2013. The researcher developed a questionnaire which consisted of (73) items.

The results indicated that there were statistically significant differences due to gender and academic year. However, results did not show statistically significant differences due to specialization or grade average. Furthermore, the results indicated that the problem of transportation was considered as the main challenge to the university administration. The need for a transportation policy was seen urgent to reduce university violence. Finally, weak religious and moral beliefs, rigid and traditional teaching methods, and the effect of local, regional, and global media all played a major role in provoking in university violence. The results also indicated that respect for human dignity received the highest average in terms of importance and practice to reduce the phenomenon of university violence.

Among the most important recommendations of the current study is working on a solution to the transportation problem and reinforcing the role of the tribe and the religious social values as well as varying and modernizing the university teaching methods and activating the role of the audio-visual and written media to keep pace with the needs of young people.
\end{abstract}

Keywords: Islamic Education, university violence, Hashemite University

\section{Introduction}

University violence is a form of community violence and is becoming an irritating phenomenon in Jordanian Universities. University students' age, difficulty to adapt to university environment, new challenges at the academic and personal levels could be among the reasons to provoke students exaggerated reactions that lead to violence.

Even though this phenomenon is new and strange to the Jordanian community, it actually is becoming an alert. Recent incidents where some students attempted to use blades and firearms are red flags for a real danger.

Various interpretations have been presented by social analysts, columnists, and university activists. Some have touched on the deteriorating tribal solidarity as a major cause for violence among the youth; others saw the arduous economic difficulties and the unhealthy family environments as reasons for violence. Still, some assume that university education poor quality, lack of university activities, unbalanced workloads and negative effects of new bad companions may also play a major factor in stirring violence on university campuses.

Damrah and Alshqar (2009), Alsaraira (2006), Al fuqaha (2001) studies had mentioned the prevalence of violence at Jordanian universities.

There are different manifestations of violence acts seen recently on Jordanian University Campuses. Such acts may vary from a non-acceptable violence behavior such as cursing and bullying to participating in a fight to using sharp instruments etc. Alsaraira (2006). Al badayneh (2006) also tries to underline some of the reasons for violence at the Jordanian universities. The study indicates that students' sense of challenge, their sense of risk, tribal solidarity, and the university intolerant laws and regulations may all be placed as reason for provoking violence. Damrah \& Al shqar (2009) have shown that university violence is mainly provoked by tribal solidarity and the lack of students' awareness of the disciplinary rules and regulation of their universities. 
The most important causes for students' violence are poor cultural education, intolerance, tribal solidarity, narcissism, and showmanship. Some other reasons are commonly associated with the university environments such as insufficient orientation, the lack of proper students' advising, inactive faculty involvement in raising students' awareness, poverty and insufficient genuine research of the phenomenon Obiedat (2011).

While university violence could be explained as a reaction of frustration and failure in performing university tasks, such violence should not involve harming and injuring individuals and university property, (Carr 2005, Smith, White, \& Holland 2003).

The wave of violence had led to four victims at Al-Hussein Bin Talal University, the killing of a student at Al-Balqa' Applied University, over the past 10 years. Up to the 2010 number of fights had accelerated to reach 776 fights with an average of 64 fights a year. Insufficient reinforcement of law against the perpetrators of violence is also a reason for the wide spread of the phenomenon, Al Twisi (2013)

The number of students engaged in university violence is still limited. Some of the solutions proposed are deepening dialogue workshops, developing communication skills courses, and creating a supportive environment for excellence and innovation, Obeidat (2011).

Some studies have attempted a classification of violence acts at Jordanian universities. Such studies revealed three types of violence: physical violence like beating, pushing, and using sharp instruments ; psychological violence such as intimidation, and imposing views on others; the third type of violence is verbal like shouting, screaming and insulting (Al Jallad 2012, Masalha 2001).

Islamic religion is the religion of peace. The word Islam is derived from the word Salam/ (Peace). Muslims greet each other by the word of peace (Alsalam 3aleikum)/ (peace be upon you). The word Alsalam had been mentioned in Holy Qur'an more than 14 times. Furthermore, Islamic beliefs and teachings confirm to rejection of violence, The Holy Qur'an says: "Because of that, We ordained for the Children of Israel that if anyone Killed a person not in retaliation of murder, or to spread mischief in the land- it would be as if he killed all mankind, and if anyone saved a life, it would be as if he saved the life of all mankind. And indeed, there came to them Our Messengers with clear proofs, evidences, and signs, even then after that many of them continued to exceed the limits ( e.g. by doing oppression unjustly and exceeding beyond the limits set by Allah by committing the major sins) in the land" (Al-Ma'idah:32).

Islam does recognize differences among people the Holy Qur'an says “ And if your Lord had so willed, He could surely have made making one Ummah [nation or community (following one religion i.e. Islam)], but they will not cease to disagree" (Hud 118). In addition, there many verses in the Holy Qur'an that call for tolerance, forgiveness, and non-violence, for example: ".. Let them pardon and forgive. Do you not love that Allah should forgive you? And Allah is Oft-Forgiving, Most Merciful” (An-Nur22), Also “... But forgive them and overlook (their misdeeds). Verily, Allah loves Al-Muhsinun (good-doers)" (Al-Ma'idah13). Moreover the Holy Quran says "So turn away from them ( O Muhammad) and say: Salam (peace)! But they will come to know" (Az-Zukhruf 89). Likewise the Holy Qur'an says "The good deed and evil deed cannot be equal. Repel (the evil) with one which is better (i.e. Allah order the faithful believers to be patient at the time of anger, and to excuse those who treat them badly) then verily he, between whom and you there was enmity, (will become) as though he was a close friend" (Fussilat34).

The Prophet's (PBUH) teachings and revelations have called for peace, understanding and forgiveness. In this area, the prophet (PBUH) says," A Muslim is the one from whose tongue and hands the Muslims are safe" (Al-bukhari). Furthermore he says "The first matter concerning which judgment will be passed among the people on the day of resurrection will be bloodshed" (Al-bukhari), He also says "O Aisha, Allah is gentle and he loves gentleness, and he rewards for gentleness what is not granted for harshness, and he does not reward anything else like it"(Al-bukhari). Additionally He says " He who is deprived of forbearance and gentleness is, in fact, deprived of all good" (Abu Daud). And when a man asked the prophet (PBUH) for an advice, he says," don't get angry"(Al-bukhari).

Violence is an act of ignorance. The prophet (PBUH had spent thirteen years in Makkah subjected to all sorts of torture, abuse, and different types of insults to him and to his companions while his continuous prayer was "O Allah! Forgive my nation, for they have no knowledge" (Al-bukhari)

In the day of conquering Makkah, the prophet (PBUH) ordered his friends to sheath their swords and to avoid any bloodshed. And when the prophet heard one of Muslims say: " Today is an epic day"; he (PBUH) replied to him:" today is a mercy day." On that day, when all nonbelievers thought that the prophet would take revenge of their brutality and torture to him, He gathered them and asked: what do you think am I going to do with you? They replied: You were a brother and a nephew to us? He looked at them and said: I set you free, this what the Holy Quran 
declares "Those who spend (in Allah's Cause) in prosperityand in adversity, who repress anger, and who pardon men; verily, Allah loves Al-Muhsinun (the good-doers)" (Al-Imran, 134).

The prophet teachings also show that Islam does not encourage brutality and the use of force. The prophet is quoted saying "the strong person is not the good wrestler. Rather, the strong person is the one who controls himself when he is angry" (Al-bukhari), and "He who points at his (Muslim) brother with a weapon is cursed by the angels."

Al-Bayhaqi $(458 \mathrm{H})$ had classified Islamic values to 77 values where Faith in Allah is on the top while least is removal of harmful object from the road. Values are the result of the learning process, so the individual learns about the values through observation and imitation (Bandura, 1963).

Values are closely linked to a collection of religious, philosophical, cultural, and educational visions. These in turn are views held by miscellaneous schools that may lead to multiple attitudes (Al Jallad1999). Values are also considered as a reflection of society, the fundamental criterion, and the individual social behavior (Abu AlAinain1988).

Islamic education represents the most important resource for values and ethics in Jordanian Islamic society. Good Morals and Honorable Behavior are seen as the core concept of the Islamic mission. The prophet said: "I was sent to perfect honorable morals" (Al-Hanbaly), and Allah sent him (PBUH) to achieve this target statement, The Holy Qur'an says "And We have send you ( O Muhammad) not but as mercy for the Alamin (mankind, Jinn and all that exists )" (Al-Anbiya107).

Is there violence in the presence of mercy and morality? The prophet (PBUH) says: "you must be compassionate; whenever there is compassion in something, it adorns it, and whenever it is removed from something it disgraces it" (Al-Tabarani), and "My mercy excels my wrath" (Al-bukhari) .

The values associated with religion are characterized as sacrosanct and benevolent. Such values include but are not limited to Honesty, Fulfillment, Justice, Charity, Modesty, Forgiveness, and Tolerance ( Al Dori \& Rushdi 1996). Henceforth, Values are major subjects of education at all educational levels (Zaher1984).

\subsection{Problem of Study}

University violence is a foreign phenomenon on Jordanian society that has been increasing since the early years of this century. Such a phenomenon has led King Abdullah II to address educational experts, university professors and the government to find serious and effective measures to counteract violence. He said in a speech, "No more Violence: our peace and security is a red line and we shall not compromise when things have to do with endangering our own future and generations."

This present research is based on several previous attempts on the same topic. Many of these studies have shown that spreading a culture of tolerance and rejecting extremism must come as the basic mission of university Al Tum (2003). Other studies (see, Al Ali, Mahafzah, \& Al-Awawdeh (2010) Abdullah and Abu-Fakhdeh(2009) Damrah \& Al-Ashqar (2009) Al-Makhareez (2006) have poked into the reasons underlying the spread of violence at Jordanian Universities. They have resulted in a general assumption that this problem requires thorough surveying of the true causes and some practical, genuine research into deriving remedies and procedural solutions to this phenomenon.

Finally, the researcher finds it true to assume that Islamic education has still more to offer in modifying students behaviors, and in finding solutions to the real factors that underlie violence among Jordanian youth Al-Tal (2003).

\subsection{Research Questions}

The current study tries to answer the following questions:

1- From students' point of view, what are the causes of violence at Hashemite University?

2- What is the effect of Islamic education on reducing university violence?

3- Are there statically, significant differences in the assessment of causes of university violence that can be related to students' major, gender, or academic level?

\subsection{Operational Definitions}

University violence is a variety of behavior forms that occur on campus whether intended or not, which are based on unequal power relationships that include specific forms of physical, psychological, and verbal violence, and intimidation and sexual harassment, or any other form of discrimination; that may have psychological or physical negative effects on the student (Al Ali, Al-Awawdeh, and Al-Mahafzah 2010). 


\subsection{Importance of the Study}

This study takes its importance from two main factors:

1) University life is one of the important phases in the student's life. This study shall try to highlight the most important causes of university violence that negatively affect students during their university years. It further shall see to what extent can Islamic Teachings and Islamic Education help in creating a safer and more convenient university environment.

2) The results of this study can be used by all concerned in Educational planning, University management and higher education policy making. The results may also be helpful for researchers in Sociology and Social Sciences in general.

\section{Review of Related Studies}

Al Ali, Al-Mahafzah and Al Awawdeh (2010) undertook a study aimed to recognize the main causes of violence between students of the Hashemite University from the students' perspective. Based on a sample of (793 male and female students) one of the most outcomes: tribal solidarity is the first reason of the university violence, male-female relationships, and family problems. The study focused on the application of penalties by the university administration as one major procedure to eliminate violence.

Damrah and Al Ashqar (2009) undertook a study aimed to recognize the causes of university violence and the proposed solutions from Irbid National University students' point of view.

The results have shown that the most common causes of university violence were the tribal solidarity, students' senate elections, sedition, and lack of awareness of discipline laws on campus. The results did not show any statistical differences related to gender or academic level in assessing the causes of violence, the proposed solutions and procedures to reduce university violence.

Abdullah and Abu Fakhdeh (2009) carried out a study aimed to identify the most important manifestations of violence among a sample of Al-Quds University. The study sample consisted of (170) male and female students. The results of the study showed that $39.2 \%$ of students have a high tendency for violence, $46.9 \%$ possessed a medium level tendency for violence, only 13.8\% had a low tendency for violence. As an outcome of this study, violence among males was more than that among females. Students' major did not seem to have any significant effect on students' tendency for violence.

Al Khatatneh (2009) undertook a study aimed to disclose of university violence forms (physical and verbal) among students who had misconduct records at Mutah University in 2005/2006. The study aimed at finding the link between causes of violence and sources of violence (personal, academic, or social). The most important results of the study was the link between personal issues and violence followed by the link between academic problems and violence.

Al Saraira (2006) conducted a study aimed to identify the causes of actual violence among Mutah University, Yarmouk University, and University of Jordan students.

The study sample consisted of (1500 male and female students) shared equally by three universities. The study revealed that harassment, physical and psychological violence and trespassing were the most common types of violence. The results also showed that males committed more violent acts than females, and they were more vulnerable to physical and psychological violence than females, while females were more vulnerable to harassment than males.

Al-Makhareez (2006) conducted a study aimed to investigate the phenomenon of student violence at state universities, in terms of occurrence intensity, causes and management. The causes were mainly related to teaching staff problems, university policies and regulations, and top administrative decisions. Psychological, social, and political causes were less important in causing violence. The study also showed that the university procedures most commonly applied to counter fight violence were penalties based on inquiry commissions' decisions and negligence and avoidance of problems. Among the reasons for violence were corruption and nepotism in employment, poor guidance from faculty members, poor awareness of the laws and regulations of the university, and avoidance of students' voice.

Oleimat and Al Sauod (2006) undertook a study aimed to measure violence among students at Jordanian state universities: Yarmouk University, Hashemite University, Al-Blqa' Applied University and Jordan University of Sciences and Technology. The study samples was made of (248) male and female students. The most important outcomes showed that males tended to be more violent than females, and that the university variable has a statistical significance, 
Which confirms the different areas of violence in the different university. It also showed that violence was higher for the colleges of humanities than their scientific counterparts.

Al Tal (2003) had conducted a study to recognize the value base among students of Al-Blqa' Applied University. Matrix values were applied on a random sample of (560 male and female students). The results indicated that the religious values came on the top of the hierarchy of value base among student's, followed by the social values, political values, aesthetic values, and finally, economic values.

Al fuqaha (2001) conducted a study aimed at identifying the factors affecting the degree of propensity for violence and aggressive behavior at Philadelphia university on a samples of (602 male and female students). The results indicated that $47.2 \%$ fell within the non-violent group, $44.3 \%$ fell within the moderately violent group a few and $0.2 \%$ only of the sample body was marked as violent. There was also a statistically significant correlation between the degree of violence and aggressive behavior among Philadelphia university students and the following independent variables: gender and family size. The variables of major and academic level as well as family income showed no statistical impact or significance on the degree of tendency and aggressive behavior.

\subsection{This Study and She Previous Studies}

This study has benefited from previous research in the matter under discussion. It depended on similar tools and adopted similar investigation measures such as the questionnaire. This study is also interested in discovering reasons that may underlie university students' tendency to violence. What makes this study of a special importance is the fact that it tries to capture the degree to which Islamic teaching and Islamic education can be used to eliminate this phenomenon. In other words, this study could be one of the rare studies that try to focus on the role played by Islamic education to counteract violence among university students.

\section{Methods}

This study follows a descriptive analytical method as it sought to identify the most important causes of university violence, at the same time look for the impact of Islamic education to reduce it, in addition to trying to find a variety of therapeutic solutions to this problem.

\subsection{Study's Sample and Society}

The study population is all students of The Hashemite University during the academic year 2012/2013, and the study sample was selected randomly. It consisted of (400) male and female students. The research tools- the questionnaires- were distributed to the sample whereas only 386 responses were obtained. Table 1 shows the distribution of the study sample by its variables:

Table 1. Study Sample classification by variables

\begin{tabular}{cccc}
\hline \multirow{2}{*}{ Gender } & Male & 131 & 33.9 \\
& Female & 255 & 66.1 \\
Major & Scientific & 114 & 29.5 \\
& Humanities & 272 & 70.5 \\
& Freshman & 211 & 54.7 \\
& Sophomore & 115 & 29.8 \\
Level & Junior & 42 & 10.9 \\
& Senior & 15 & 3.9 \\
& More than that & 3 & .8 \\
& Less than 2 & 27 & 7.0 \\
Grade average & $2 / 2.50$ & 108 & 28.0 \\
& $2.51 / 3.50$ & 217 & 56.2 \\
& $3.51 / 4.00$ & 34 & 8.8 \\
\hline
\end{tabular}




\subsection{Tools and Measures}

The researcher used questionnaire as an investigation tool. It has been developed after the distribution of an open question to a sample of students at Hashemite University. The current study had benefited from theoretical literature and previous studies in this field ( see for example: Al Ali, Mahafzah, and Al-Awawdeh (2010), Hendi and Al-Shudaifat (2010), Abdullah and Abu Fakhdeh (2009), Damrah and Al Ashqar (2008), and Al Tal (2003).

The questionnaire consisted of three sections:

- Section one is general information

- Section two consisted of two columns: one showed the items that included the Islamic value while the other column showed the degree of awareness according to the student's response.

- Section three is about the causes of university violence, and there was an open question at the end of the questionnaire.

\subsection{Study Tool Validity and Reliability}

Special concern was given to the validity and reliability of the tool and proper statistics for validation were applied. Cronbach Alpha and Peer Review were used to assess internal and external consistency and the tool passed at the level of $82 \%$.

Study Limitations:

This study is limited in scope to the sample of Hashemite University students in Al-Zarqa' governorate for the academic year 2012/2013.

\subsection{Data Analysis and Statistics}

The study applied standard deviation, means and T-Test to analyze and evaluate the sample responses to the questionnaire.

\section{Discussion of Results}

The study presents below the results of the questionnaire after the proper analysis of the gathered responses. The results are presented in accordance with the study questions presented in the introduction.

1) What are the causes of university violence at The Hashemite University from the students' point of view?

Table 2. The first field (causes related to university policy and management)

\begin{tabular}{ccccc}
\hline $\begin{array}{c}\text { Item } \\
\text { number }\end{array}$ & Paragraph & Mean & $\begin{array}{c}\text { Standard } \\
\text { deviation }\end{array}$ & Degree \\
\hline 17 & Transportation problems & 4.40 & 1.09 & 1 \\
9 & Nepotism & 4.26 & 1.11 & 2 \\
7 & Failure to listen to students complaints & 3.98 & 1.18 & 3 \\
10 & Weak social and psychological counseling & 3.82 & 1.10 & 4 \\
15 & Improper attention to religious education about violence & 3.81 & 1.22 & 5 \\
18 & Lax law & 3.80 & 1.21 & 6 \\
14 & disconnect among students and ID office & 3.75 & 1.20 & 7 \\
16 & Improper social education about violence & 3.72 & 1.16 & 8 \\
12 & department heads and deans show little concern to students' & 3.70 & 1.23 & 9 \\
1 & problems. & 3.69 & 1.09 & 10 \\
3 & Making exceptions in admissions policy & 3.62 & 1.21 & 11 \\
11 & Inadequate disciplinary proceedings & 3.59 & 1.16 & 12 \\
8 & Weak academic Counseling and Guidance & 3.58 & 1.35 & 13 \\
13 & Mistreatment by admin staff to students & 3.40 & 1.24 & 14 \\
6 & Student's dissatisfaction with university regulations & 3.35 & 1.35 & 15 \\
5 & Registration system & 3.30 & 1.34 & 16 \\
2 & Too much waste time between lectures & 3.22 & 1.31 & 17 \\
4 & Scholarship regulations & 3.16 & 1.32 & 18 \\
& Credit-hours system & 2.33 & 0.33 & \\
\hline
\end{tabular}


Table 2 clearly shows that item 1 (Transportation Problems) came with the highest mean of 4.40. This result can be interpreted in the light of the following: First, the Hashemite University site is in a semi-isolated geographical area in terms of traffic; it is located in a remote area between two major governorates. This keeps the university a little isolated from major traffic routes. In addition to that, the vast change in University size and number of admitted students does also add to the transportation problem. The University although was open in 1995, now has more than 24000 thousand students. Therefore, the high number of students and distance from major transportation routes as well as the absence of proper public transportation companies in Jordan all created a real havoc for students especially in the evening hours and in Winter. Some, under the pressure of such circumstances may retreat to violence. Finally, university admission for students returning from Yemen, Syria and other countries had led to a sharp increase that has created additional complications to the transportation problems.

Table 3. The second field (student related causes: social, psychological, economic factors)

\begin{tabular}{|c|c|c|c|c|}
\hline $\begin{array}{c}\text { Item } \\
\text { number }\end{array}$ & Paragraph & Means & $\begin{array}{l}\text { Standard } \\
\text { deviation }\end{array}$ & Degree \\
\hline 27 & Weak religious and moral conscience & 4.51 & 0.93 & 1 \\
\hline 19 & Tribal solidarity & 4.25 & 1.05 & 2 \\
\hline 20 & Emotional relationships & 4.24 & 1.00 & 3 \\
\hline 26 & Bad company & 4.23 & 1.09 & 4 \\
\hline 28 & $\begin{array}{c}\text { Male student showing up opposite female } \\
\text { student }\end{array}$ & 4.19 & 1.04 & 5 \\
\hline 33 & Life pressure & 4.04 & 1.03 & 6 \\
\hline 29 & Repeated academic failure & 3.88 & 1.07 & 7 \\
\hline 21 & $\begin{array}{l}\text { Differing levels of social and cultural } \\
\text { background }\end{array}$ & 3.75 & 1.00 & 8 \\
\hline 25 & Law economic status for student & 3.70 & 1.15 & 9 \\
\hline 24 & Copying others & 3.66 & 1.22 & 10 \\
\hline 30 & Narrow regional affiliations & 3.56 & 1.13 & 11 \\
\hline 22 & $\begin{array}{l}\text { Not engaging in meaningful university } \\
\text { activities }\end{array}$ & 3.45 & 1.11 & 12 \\
\hline 32 & Poor self-image student & 3.45 & 1.24 & 13 \\
\hline 23 & Family problems & 3.36 & 1.20 & 14 \\
\hline \multirow[t]{2}{*}{31} & $\begin{array}{l}\text { Lack of involvement in university } \\
\text { activities }\end{array}$ & 3.36 & 1.20 & 15 \\
\hline & Total & 3.84 & 0.38 & \\
\hline
\end{tabular}

It is noticed from Table 3, that the weakness of religious and moral conscience has reached the highest mean. Religion, as it is known, shapes human morals and regulates his behavior. It also teaches human patience, tolerance and compassion, and these are the genuine ethics of Islam: Our prophet Mohamed (PBUH) said:" I was sent to perfect honorable morals"(Al Hutaimi). Also the Holy Quran says to Mohamed (PBUH) "And Verily, you (O Mohamed) are on an exalted (standard of) character" (Al-Qalam: 4). As Aisha said:" his manner was a Qur'an" (Al Albani).

One student wrote:" the most important causes of university violence is the weakness of moral conscience and admission of student, who are not qualified for education at our university."

Someone else wrote:" the development of ethics and the feelings for others depart from the tribal solidarity, help develops a culture of tolerance and forgiveness even if one is able to punish."

Someone else wrote:" Allah created us peoples and tribes to know each other and live together not to differ or divide; Allah has ranked people high for their piety not their color or gender."

Someone else wrote:" in my personal opinion, the phenomenon of violence is oversized, and it shouldn't be given more than its actual size, though I hope that dress code be applied on campus." One of the students wrote:" I hope to see 
seminars held by the deanship of student affairs that encourage students to write articles focusing on strengthening the students' religious values."

Someone also wrote:" Islamic education has a strong impact on university violence. When you are offered an Islamic lecture, students will be influenced by the speaker, especially if the speaker can stand as a good behavioral model for his students in real life."

Lack of involvement in university activities has obtained the lowest mean which can be explained by the fact that some students only care about the grade average; In this case, students may not be very interested in university activities, and some activities do not meet student's actual needs.

Table 4. The third field (causes related to the academic staff)

\begin{tabular}{ccccc}
\hline $\begin{array}{c}\text { Item } \\
\text { number }\end{array}$ & Paragraph & Mean & $\begin{array}{c}\text { Standard } \\
\text { deviation }\end{array}$ & Degree \\
\hline 40 & Undiversified and traditional teaching methods & 3.82 & 1.18 & 1 \\
37 & Students' Grades and Favoritism & 3.81 & 1.28 & 2 \\
39 & Improper Academic treatment of students & 3.74 & 1.15 & 3 \\
34 & Discrimination among students & 3.72 & 1.26 & 4 \\
35 & Low respect to students & 3.57 & 1.30 & 5 \\
38 & Bad relationships between faculty members and students & 3.52 & 1.25 & 6 \\
36 & Weak academic level for faculty members & 3.13 & 1.26 & 7 \\
& Total & 3.62 & 0.24 & \\
\hline
\end{tabular}

It is noted from Table 4 that item 40 " Undiversified and traditional teaching methods" has got the highest mean in this field. This can be referred to two major issues: one is the fact that most university professors did not have a proper pedagogy training as most of them joined the University directly after obtaining their highest degree in their specialty area but had never had any teaching practice. Second, there could be the lack of experience in using technology in teaching; this could explain why most of them tend to use lecturing most of the time.

One student wrote:" study is a book memorized and then a grade; it is not to apply what one learns. I hope to develop the process of teaching and learning in Jordan to become a process tied to our needs, not for reading and memorize to getting grades."

It is noted from Table 4, that item number 36 "weak academic level of faculty members" has got the lowest Mean. Hashemite University is still recent University and most faculty are young people who graduated from excellent universities in The US, Canada and Europe. Therefore, the faculty issue is not related to their academic level in their areas of specialization; it could be only in their experience in teaching techniques.

Table 5. Fourth field (political, internal or external causes)

\begin{tabular}{ccccc}
\hline $\begin{array}{c}\text { Item } \\
\text { No. }\end{array}$ & Paragraph & Mean & $\begin{array}{c}\text { Standard } \\
\text { deviation }\end{array}$ & Degree \\
\hline 44 & Influence of local, regional and international media & 3.56 & 1.28 & 1 \\
43 & Influence of political affiliations outside university & 3.53 & 1.18 & 2 \\
42 & Lack of loyalty and belonging to the state & 3.39 & 1.13 & 3 \\
41 & Low level of political participation & 3.30 & 1.20 & 4 \\
& Total & 3.45 & 0.12 & \\
\hline
\end{tabular}

It is noted from Table 5, that the item 44 has got the highest Mean in this field; it could be explained by the great advances in media and Internet that the world has witnesses since the advent of the 21 century. In addition, the availability of internet and satellite in almost every home in the country has made the world a small village. This of course has increased human interaction and at the same time exchange of ideas and feelings.

Item 41 has got the lowest Mean, as political parties do not exactly mean much for many students in Jordan. None of the political parties in Jordan has managed to convince students to join the political life in Jordan.

2) What is the effect of Islamic education on reducing university violence? 
To answer this question, we directed a question to the participating students about the importance of values held by students from their point of view, and about their actual practice of values that may reduce the phenomenon of violence at the Hashemite University.

In addition, we directed an open question for students about what contribution does Islamic education have in addressing university violence?

Table 6 below shows the Means and standard deviations for the sample responses.

Table 6. This table shows the Means and standard deviations for the importance of Islamic values and their actual practice

\begin{tabular}{|c|c|c|c|c|c|c|}
\hline \multirow[b]{2}{*}{ Item } & \multicolumn{3}{|c|}{ Criticality } & \multicolumn{3}{|c|}{ Degree of practice } \\
\hline & Mean & $\begin{array}{l}\text { Standard } \\
\text { deviation }\end{array}$ & Level & Mean & $\begin{array}{l}\text { Standard } \\
\text { deviation }\end{array}$ & level \\
\hline Respect for human dignity & 2.92 & 0.28 & 1 & 2.77 & 0.47 & 1 \\
\hline $\begin{array}{c}\text { Pride in a culture of peace and reject } \\
\text { violence }\end{array}$ & 2.82 & 0.44 & 2 & 2.63 & 0.59 & 6 \\
\hline Preserve people life & 2.77 & 0.46 & 3 & 2.67 & 0.55 & 3 \\
\hline Respect the other & 2.73 & 0.53 & 4 & 2.65 & 0.58 & 5 \\
\hline Love Goodness for others & 2.72 & 0.49 & 5 & 2.69 & 0.53 & 2 \\
\hline Deal with others with a smile & 2.68 & 0.49 & 6 & 2.56 & 0.60 & 9 \\
\hline $\begin{array}{c}\text { Be brave and courageous bit not } \\
\text { reckless. }\end{array}$ & 2.67 & 0.52 & 7 & 2.50 & 0.63 & 13 \\
\hline Force is the only way to solve problems & 2.67 & 0.55 & 8 & 2.53 & 0.62 & 11 \\
\hline Use your brain instead not your hand & 2.67 & 0.57 & 9 & 2.55 & 0.63 & 10 \\
\hline Preserve university and its properties & 2.65 & 0.53 & 10 & 2.66 & 0.56 & 4 \\
\hline Be humble but not arrogant. & 2.65 & 0.55 & 11 & 2.59 & 0.57 & 7 \\
\hline Don't look down at people & 2.65 & 0.54 & 12 & 2.58 & 0.59 & 8 \\
\hline Have confidence & 2.63 & 0.55 & 13 & 2.38 & 0.68 & 20 \\
\hline Choose your friends carefully & 2.63 & 0.60 & 14 & 2.52 & 0.63 & 12 \\
\hline $\begin{array}{l}\text { Adopting dialogue and discussion for } \\
\text { understanding others }\end{array}$ & 2.62 & 0.52 & 15 & 2.47 & 0.60 & 15 \\
\hline Respect your beliefs with no bias. & 2.60 & 0.56 & 16 & 2.44 & 0.70 & 18 \\
\hline $\begin{array}{l}\text { Respect for others' freedom of expression } \\
\text { and opinion }\end{array}$ & 2.58 & 0.53 & 17 & 2.46 & 0.63 & 16 \\
\hline Like order and discipline & 2.57 & 0.61 & 18 & 2.45 & 0.67 & 17 \\
\hline Respect others' beliefs & 2.56 & 0.54 & 19 & 2.41 & 0.60 & 19 \\
\hline Leniency of others & 2.55 & 0.58 & 20 & 2.47 & 0.60 & 14 \\
\hline Anger management & 2.45 & 0.62 & 21 & 2.19 & 0.70 & 24 \\
\hline Moderate spending and no extravagance & 2.43 & 0.67 & 22 & 2.22 & 0.74 & 23 \\
\hline Amnesty and pardon of others & 2.43 & 0.56 & 23 & 2.26 & 0.64 & 22 \\
\hline Forgiveness and not replying offenses & 2.42 & 0.62 & 24 & 2.16 & 0.71 & 25 \\
\hline $\begin{array}{l}\text { Differences of opinion do not upset good } \\
\text { relations }\end{array}$ & 2.41 & 0.65 & 25 & 2.33 & 0.70 & 21 \\
\hline Invest your time positively on campus & 2.35 & 0.66 & 26 & 2.11 & 0.73 & 27 \\
\hline $\begin{array}{l}\text { Respect for political pluralism in } \\
\text { university }\end{array}$ & 2.26 & 0.71 & 27 & 2.14 & 0.74 & 26 \\
\hline Take in criticism & 2.23 & 0.66 & 28 & 2.08 & 0.72 & 29 \\
\hline Participate in the social life on campus & 2.21 & 0.70 & 29 & 2.09 & 0.74 & 28 \\
\hline
\end{tabular}


It is noted from table 6, that the item "Respect for human dignity" has got the highest Means for each of criticality and degree of practice, which really means that students are aware of respect for human dignity, The Holy Quran says " And indeed We have honoured the Children of Adam, and We have carried them on land and sea, and have provided them with At-Tayyibat (lawful good things), and have preferred them to many of those whom We have created with a marked preferment" (Al-Isra' 70).

As interpreted through Al-Jalalain, Allah preferred a human from all other creatures with knowledge, speech and shape.

As interpreted through Al-Jabari, the premises of preference are creating the hands of man in this way, thus how is he using it for oppression violence and abuse?

We recall here Abel's saying to his brother Cain as stated in the Holy Qur'an states "If you do stretch your hand against me to kill me, I shall never stretch my hand against you to kill you: for I fear Allah, the Lord of the Allamin (mankind, jinn, and all that exists" Al-Ma'idah:28.

In addition, when Allah makes reference to a man, He created Sons of Adam by his hands and blew into them of his soul. Man is infallible of blood and therefor Allah made provisions and retributions for deadly acts. The prophet Mohamed (PBUH) said:" he who points at his (Muslim) brother with a weapon is cursed by the angles" (Al Termizy).

And respect for human dignity and nice speech are seen as virtues in Islam. The prophet (PBUH) said:" saying a good word is also Sadaqa" (Al-bukhari), and he said:" he who believes in Allah and the Last Day, let him speak good or remain silent" (Muslim).

The second paragraph of criticality was "pride in a culture of peace and rejecting violence." In practice, however it ranked sixth. This can be explained by the fact that students believe in the importance of renouncing violence and peace but they don't practice that whenever they are angry. The prophet Mohamed says:" the strong man is not one who is good at wrestling, but the strong man is one who controls himself in a fit of rage"(Al-bukhari).

The paragraph "participation in the social life on campus" has got the last rank in the order of criticality and second last rank in terms of practice and this can be explained by linking this result to the result of the first question, "lack of involvement in university activates" which has got the lowest means. This can be further explained by the fact that neither the students nor the university has made clear attempts to create activities that can help students become active and productive members on campus. Many students just come to take lectures and go and many others don't have any idea of what to do in their free time.

One student wrote:" one of the causes for university violence is the psychological pressure on students and free time. They are not directed to discharge positively in a manner that can benefit them and their university and society." Someone else wrote:" I suggest, as a solution to violence, increasing Islamic education at the university and probably making it a mandatory university requirement same like as Arabic and English."

3) Are there statistically significant differences in the assessment of the students' point of view that can be related to the major (science, humanities) year/level or gender?

To answer this question, Means and standard deviations were extracted and calculated; and to check on the statistical significance in respect of major and gender, C-test was applied, and finally one-way analysis of variance was used to investigate the effect of academic year/level and grade average variables. The results showed some statistical significance related to gender while there were not any statistically significant differences for the variables of major and academic year as shown in the following tables $7,8,9$. 
Table 7. Means, standard deviations, value $\mathrm{C}$, and One-way analysis of variance for study variables (gender, major, academic year and grade average)

\begin{tabular}{|c|c|c|c|c|c|c|c|c|}
\hline Field & Variable & Population & Means & $\begin{array}{l}\text { Standard } \\
\text { deviation }\end{array}$ & Value of $\mathrm{P}$ & $\begin{array}{l}\text { Degree } \\
\text { of } \\
\text { freedom }\end{array}$ & $\begin{array}{c}\text { Value of } \\
\text { C }\end{array}$ & $\begin{array}{c}\text { Statistical } \\
\text { significance }\end{array}$ \\
\hline \multirow{2}{*}{$\begin{array}{c}\text { (Causes for } \\
\text { university policy } \\
\text { and management) }\end{array}$} & Male & 131 & 65.1221 & 10.37602 & \multirow[b]{2}{*}{.408} & \multirow[b]{2}{*}{384} & \multirow[b]{2}{*}{$-1.346-$} & \multirow[b]{2}{*}{.179} \\
\hline & Female & 255 & 66.6784 & 10.95115 & & & & \\
\hline $\begin{array}{l}\text { (Causes for } \\
\text { students }\end{array}$ & Male & 131 & 57.6183 & 8.33755 & & & & \\
\hline $\begin{array}{l}\text { themselves social, } \\
\text { psychological and } \\
\text { economical) }\end{array}$ & Female & 255 & 57.6314 & 9.67653 & 2.623 & 384 & $-.013-$ & .990 \\
\hline \multirow{2}{*}{$\begin{array}{l}\text { (Causes related to } \\
\text { academic staff) }\end{array}$} & Male & 131 & 24.1298 & 6.47409 & \multirow{2}{*}{3.591} & \multirow{2}{*}{384} & \multirow{2}{*}{$-2.745-$} & \multirow{2}{*}{$* .006$} \\
\hline & female & 255 & 25.9216 & 5.85468 & & & & \\
\hline \multirow{2}{*}{$\begin{array}{l}\text { (Political internal } \\
\text { or external } \\
\text { causes) }\end{array}$} & Male & 131 & 13.7481 & 3.82772 & \multirow[b]{2}{*}{1.459} & \multirow[b]{2}{*}{384} & \multirow[b]{2}{*}{$-.124-$} & \multirow[b]{2}{*}{.901} \\
\hline & female & 255 & 13.7961 & 3.47850 & & & & \\
\hline \multirow{2}{*}{ Total } & Male & 131 & 307.4885 & 40.93811 & \multirow{2}{*}{2.019} & \multirow{2}{*}{384} & \multirow{2}{*}{$-1.406-$} & \multirow{2}{*}{.160} \\
\hline & female & 255 & 314.2588 & 46.63322 & & & & \\
\hline
\end{tabular}

It is noted from Table 7, that there were not any statistically significance differences in students' responses due to gender on any item of the questionnaire. Expect for the field "causes related to academic staff", the alpha value is 0.006 , which indicates the existence of a difference statically indicative at the level of significance of $0.005 \geq$ in favor of males with a Means was 24.1296 and, a standard deviation of 6.47409.

Table 8. One-way analysis of variance for academic variable

\begin{tabular}{|c|c|c|c|c|c|c|}
\hline Field & Source of variation & Total squares & $\begin{array}{l}\text { Degrees of } \\
\text { freedom }\end{array}$ & $\begin{array}{l}\text { Average } \\
\text { squares }\end{array}$ & Value $\mathrm{P}$ & $\begin{array}{c}\text { Level of } \\
\text { significance }\end{array}$ \\
\hline \multirow{3}{*}{$\begin{array}{c}\text { (Causes for } \\
\text { university policy } \\
\text { and management) }\end{array}$} & Between groups & 856.495 & 4 & 214.124 & 1.862 & .116 \\
\hline & Within groups & 43810.790 & 381 & 114.989 & & \\
\hline & Total & 44667.285 & 385 & & & \\
\hline \multirow{3}{*}{$\begin{array}{l}\text { (Causes for } \\
\text { students } \\
\text { themselves } \\
\text { social, } \\
\text { psychological } \\
\text { and economical) }\end{array}$} & Between group & 492.185 & 4 & 123.046 & 1.450 & .217 \\
\hline & Within groups & 32328.095 & 381 & 84.851 & & \\
\hline & Total & 32820.280 & 385 & & & \\
\hline \multirow{3}{*}{$\begin{array}{c}\text { (Causes related to } \\
\text { academic staff) }\end{array}$} & Between group & 400.576 & 4 & 100.144 & 2.719 & $* .029$ \\
\hline & Within groups & 14032.494 & 381 & 36.831 & & \\
\hline & Total & 14433.070 & 385 & & & \\
\hline \multirow{3}{*}{$\begin{array}{l}\text { (Political internal } \\
\text { or external } \\
\text { causes) }\end{array}$} & Between group & 119.223 & 4 & 29.806 & 2.337 & .055 \\
\hline & Within groups & 4859.060 & 381 & 12.753 & & \\
\hline & Total & 4978.282 & 385 & & & \\
\hline \multirow{3}{*}{ Total } & Between group & 18961.278 & 4 & 4740.320 & 2.391 & $* .050$ \\
\hline & Within groups & 755239.139 & 381 & 1982.255 & & \\
\hline & Total & 774200.417 & 385 & & & \\
\hline
\end{tabular}


Table 8 shows that there are statistically significant differences in students' responses due to the academic year in general on the questionnaire. Alpha value is 0.05 which indicates the existence of one difference which is statistically indicative at the level of significance alpha $\geq 0.005$. In addition, there are statistically significant differences in the field " causes related to academic staff " with an Alpha value of 0.029.

To find out if student academic level or school year plays a significant difference on the trend of violence, Scheffe' test was used for multiple comparisons as shown in tables 9,10.

Which shown the difference due to a field of "causes for teaching staff" and for students who have studied for more than four years

The test also showed the same results in respect to the whole questionnaire. This can be explained by the fact that students who have studied for four years or more, have gained an advantage over newly admitted students.

Table 9. Scheffe' test for multiple comparisons (for third field)

(Causes related to academic staff)

\begin{tabular}{cccccc}
\hline & First & Second & Third & Fourth & More than that \\
\hline First & & & & $0.002^{*}$ \\
Second & & & & $0.004^{*}$ \\
Third & & & & $0.003^{*}$ \\
Fourth & & & & $0.007^{*}$ \\
More than that & $0.002^{*}$ & $0.004^{*}$ & $0.003^{*}$ & $0.007^{*}$ & \\
\hline
\end{tabular}

Table 10. Scheffe' test for multiple comparisons as a whole test

\begin{tabular}{|c|c|c|c|c|c|}
\hline & First & Second & Third & Fourth & More than that \\
\hline First & & & & & $0.008 *$ \\
\hline Second & & & & & $0.012^{*}$ \\
\hline Third & & & & & $0.003^{*}$ \\
\hline Fourth & & & & & $0.013^{*}$ \\
\hline More than that & $* 0.008$ & $0.012 *$ & $0.003 *$ & $0.013 *$ & \\
\hline
\end{tabular}

Table 9 and 10 show that there are no statistically significant differences in students' responses to the overall fields of the questionnaire where all values came a statistical significance of $>0.05$.

\section{Conclusion and Recommendations}

In light of the data and the analysis presented so far and in comparison with the results of previous research in the related areas, the researcher concludes that university violence is a fad not necessarily a trend. It could be a direct influence of violence presented on TV every day especially that Jordan is surrounded by neighboring countries that suffer from all sorts of violence. Another possible factor is the social and economic situation in the country that has been tremendously affected by the influx of immigrants from neighboring states such as Syria, Yemen, Iraq, Palestine and Libya. Notwithstanding the reasons revealed by this study, namely the transportation issue, the lack of Islamic education, the insufficient teacher training for academic staff and the insufficient attention given to social and cultural activities on campus, students need to have some new life on campus that helps them discharge their problems in a more positive and constructive way. It is seen critical at this point that the university administration finds new ways to listen to students' voice and creative ways to fulfill their needs and aspirations.

In this respect, the study ends up with the following recommendations:

- More attention should be given to moral and ethical values in the curriculum.

- Paying more attention to developing teaching styles and teaching techniques. Academic Staff must enjoy a better level of professionalism in pedagogy.

- finding a quick and suitable solution to transportation problems

- Giving more importance to family, tribal and community ties that will lead to fostering social respect and acceptance.

- Better investment of media and social media to fulfill students' needs and aspirations. 


\section{Acknowledgment}

I would like to give my sincere thanks to the Hashemite University for all facilities and financial support. I would like to thanks the students for cooperation and take part in this study.

\section{References}

Abdullah, Tayseer, \& Juma Abu Fakhdeh. (2009). Quds University students' attitude towards University Violence. Journal of Arab Universities League, (2), Pp. (549-599).

Abu Al Alinain, Ali. (1988). Islamic Values and Education. $7^{\text {th }}$ edition. Ibrahim Al Halabi Publisher. Al Madinah Al Munawarh, KSA.

Abu Daaud. Suleiman bin Al Ashaath. Editedd by Izzat Al Daas. Sunan Abi Dawood. Dar Al AL Kutub AL Ilmyeh (publisher) 4809.

Al Al Bani, Mohammad, Sahih AL Jami. Edited by Al SHawish, Zuhair. Al MAktab Al Islami. Modern Encyclopedia: 4811.

Al Ali, Yahyia, Mahafzah, Mohammad, \& Al Awawdeh, Amal. (2010), University Violence - Reasons for University Violence at Al Hashemite University from Students' Perspective. Social Affairs, (106). Pp.(127-151).

Al Badayneh, D. (2006). Violence in Jordan Society. A paper presented at the Symposium "Violence at our University - Towards a safe Society. 6/8/2006

Al Bayhaqi, Ahmad, Shaab AL Iyman. Dar Al Turath (publisher), 5458. Cairo.

Al Dori, Qahtan, \& Rushdi, (1996). Principles of Islam. Dar AL Fikr, Amman, Jordan.

Al Fuqaha, Isam, (2001). Level of Tendency to Violence at Philadelphia University and its relation to Gender, Major, College, Academic Achievement and Family income. Journal of Educational Sciences, (2)/12. Pp. (4574-4588).

Al Ghazali, Mohammad. Fiqh Al Serah. Edited by Mohammad Al Albani. Dar Al Qalam(publisher), 103.

Al Hutaimi, Ali Bin ABi Baker. Majma AL Zawaed. Dar Al Kitab Al Arabi. Modern Encyclopedia 9/18.

Al Jalad, Majid. (1999), Value System from an Islamic Education Perspective. Journal of Educational Sciences and Psychology, 32(70-99).

Al Jallad, R. (2012). Violent Behavior and the socio-economic factors. Unpublished MA Thesis. Amman Arab University.

Al Khatatneh, Ola. (2007). Forms of University Violence at Mu'ta University and their causes from students' perspective. Unpublished MA thesis - Mu'ta University.

Al MAkhareez, Lafi. (2006). University Students' Violence at Jordanian Public Universities: Causes and ramifications by Students Affairs.

Al Naysabouri, Muslem, Sahih Muslem. Edited by Mohammad Abd Al Bagi. Dar Ihya Al Kutub Al Arabiya (publisher), 2619.

Al Qaisi, Ali (2013). University Violence: some causes. Alrai Newspaper 22/5/2013.

Al Saraira, N. (2006). Violence Statuesque at State Universities in Jordan: Muta University, University of Jordan and Yarmouk University. Unpublished MA thesis.

Al Tabarani, Suleiman. Editied by Al Huseini Tareq. Dar Al HAramein: Modern Encyclopedia, 344/2.

Al Tal, Shadya. (2003). The System of Values for Al Zarqa Private University students. Mu'ta for Research, (1) 18 (11-42).

Al Termizy, Mohammad, Sunan Al Tirmidi. Edited by Ahmad Shaker. Dar Ihya Al Turath Al Arabi. Modern Encyclopedia: 2162.

Al Tum, Mohammad. (2003). Social and Psychological Counseling and its Role in Students' Service. Al Khurtum University. The Sudan.

Al Twaisi, B. (2013). Violence at Jordanian Universities: An outcome of unsuccessful Change Attempts. Al Jazeer 9/5/2013.

Al-Bukhari, M. from Sahih Al Bukhari, Al Mousoua Al Hadithah, Sahaih Al Bukhari. Dar Ihyaa Alturath Al Arabi. 6484,6533, 6927, 6116,3477, 6114, 1385, 7422, 2989, 6114. 
Al-Hanbaly, Abdulrahman, Lataif Al Marif. Edited by Um Amer Al Atrubi. Al Haramein for Useful Science Publisher. 305.

Bandura, A., \& Walters, R.H. (1963). Social learning and personality development. Holt Rinehart and Winston: New York.

Carr J. (2007).Campus violence white paper. Journal of American college health. Pages 304-319, https://doi.org/10.3200/JACH.55.5.304-320

Damrah, J., \& Wafa Al Ashqar. (2009). Causes for university violence and Suggested solutions from the students' perspective of Irbid Private University. Irbid for Research Studies, 12(2), 251-283.

Hendi, Saleh, \& Al Shudaifat, Sadeq. (2013). Values of Forgiveness at the Hashemite University National Education Curriculum. Jordanian Journal of Islamic Studies, 9(3), 63-78.

Masalha, M. (2001). Defeating Violence by Creative Thinking. Center for Applied Studies. Jerusalem.

Obeidat, M. (2011). Violence at Jordanian Universities... what next? Yarmouk University News Network 20/5/2013.

Oleimat, Mohammad, \& Lubna Al Sauod. (2006). Vieolence at Jordanian Public Universities: Forms, causes and remedies. Culture and Development (16).

Rodney, H., Tachia, H., \& Rodney, L.(1997). The effect of family and social support on feelings and past acts of violence among African-American college Men. Journal of American College Health, 46(3), 103-108. https://doi.org/10.1080/07448489709595595

Smith ,P., White ,W., \& Holland,L. (2003). A longitudinal perspective on dating violence among adolescent and college -age women. American journal of public health, 93(1), 1107-1109. https://doi.org/10.2105/AJPH.93.7.1104

Zaher, Dhya. (1984). Values in the Education Process. Arabian Gulf Foundation: Cairo. 